\title{
The Effect of Coriander Ethanol Extract (Coriandrum sativum L.) Against Phagocytosis Activity and Capacity of the Macrophage Cells and the Percentage of Leukocyte Cells in White Male Mice
}

\author{
Dwisari Dillasamola*, Yufri Aldi, Marselani Kolobinti
}

\section{Dwisari Dillasamola*, Yufri} Aldi, Marselani Kolobinti

Faculty of Pharmacy, Department of Pharmacology, Andalas University, Padang, INDONESIA.

\section{Correspondence}

\section{Dwisari Dillasamola}

Faculty of Pharmacy, Department of Pharmacology, Andalas University, Padang, INDONESIA.

E-mail: dwisaridillasamola@phar.unand.ac.id History

- Submission Date: 23-07-2019;

- Review completed: 16-08-2019;

- Accepted Date: 16-08-2019.

DOI : 10.5530/pj.2019.11.200

Article Available online http://www.phcogj.com/v11/i6

\section{Copyright}

(C) 2019 Phcogj.Com. This is an openaccess article distributed under the terms of the Creative Commons Attribution 4.0 International license.

\begin{abstract}
Coriander has long been used by humans as a traditional drug and to enhances the taste of foods. This study aims to know the effects of coriander ethanol extract against phagocytosis activity and capacity of the macrophage cells and the percentage of leukocytes. The test animals used were white male mice which divided into 4 groups and each group consists of 5 mice. The first group (control) was given with $0.5 \% \mathrm{Na} C M C$ suspension. The second, the third, and the fourth groups were given with coriander extract each with doses of 100 $\mathrm{mg} / \mathrm{kg}, 140 \mathrm{mg} / \mathrm{kg}$ and $200 \mathrm{mg} / \mathrm{kg}$ orally for 7 days long. On the 8th day, the mice were induced by Staphylococcus aureus to help their immune system. The results showed that the administration of coriander extract at doses of 100,140 and $200 \mathrm{mg} / \mathrm{kg}$ can increase the phagocytic activity of macrophages by $44.6 \% ; 54.2 \%$; and $60.2 \%$ each, while the phagocytic capacity replaces the results of $95.8 ; 104.4$; and 126 cells. The total number of leukocytes showed were 5210, 6190, and $7310 / \mu \mathrm{L}$ blood. In the number of leukocyte cells, the amount of coriander extract can reduce the number of neutrophil and monocyte cell segments. The conclusion of this study regarding coriander ethanol extract at doses of 100, 140 and 200 $\mathrm{mg} / \mathrm{kg}$ can increase phagocytosis activity and capacity of the macrophage cells and the total leukocyte cell counts in male white mice.
\end{abstract}

Key words: Coriandrum sativum, Activity, Phagocytosis capacity, Macrophages, Leukocytes.

\section{INTRODUCTION}

Immunity is protection against diseases, especially infections. The responsible cells and molecules for immunity are called the immune system. When the function and the number of immune cells are inadequate, exposure to pathogenic microorganisms can cause various diseases, especially infectious diseases. The main purpose of the immune system is to defend the body from the attack of microorganisms. ${ }^{1}$ The immune system can be divided into nonspecific and specific immune systems. One cell in the nonspecific immune system which acts as the first defence against the attack of microorganisms named phagocytic cells. ${ }^{2,3}$ One phagocyte cell that plays an important role in the immune system is a component of white blood cells (leukocytes) named monocytes. Monocytes are present in the blood circulation and when those migrated to the tissue they will differentiate into macrophages. ${ }^{4}$ Macrophages are cells that play an important role in the body's immune system against pathogens. One of the main roles of macrophages in the natural immunity system is the function of phagocytosis, which aims to eliminate extracellular particles, damaged or dead cells, and pathogenic bacteria. ${ }^{5}$ The body's defence mechanism against the attack of microorganisms can be increased by the presence of immunomodulatory compounds named compounds that can increase the body's defence both specific and non-specific needed for the treatment of infectious diseases, immunodeficiency, and malignancy (cancer). At this time, more research is being developed to look for medicinal ingredients derived from nature. The medicinal plant that has the potential as immunomodulators is coriander (Coriandrum sativum L.). Coriander is a type of spice plant which very well known among people as a spice. Coriander has long been used by humans as a medicine or to improve the taste of foods. ${ }^{6}$ Various parts of this plant such as the seeds, leaves, flowers, and fruits have been reported to have diuretic activity, antioxidants, antidiabetic, anticonviction, sedative, antimicrobial, anti-mutagenic, antihelmintic, to treat hiccups, pus, inflammation, toothache, jaundice, and scabies. $^{7-10}$ Various studies have been conducted to test the activity of coriander, but none has conducted any research on the activity of coriander against the immune system.

\section{MATERIALS AND METHODS}

\section{Time and place of the research}

This research was implemented from January to March 2019 in the Research Laboratory and the Laboratory of Immunology \& Serology at the Faculty of Pharmacy, Andalas University.

Tools

The tools used were glass (Pyrex), gloves (Sens), masks (Sensi), sonde needles (Onemed), filter paper (Whatman), syringes (Onemed), measuring cups (Pyrex), analytical scales (Ohaus), microscope

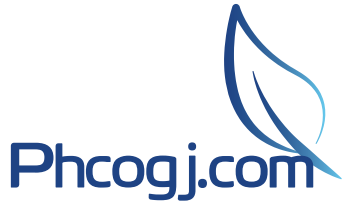

Cite this article: Dillasamola D, Aldi Y, Kolobinti M. The Effect of Coriander Ethanol Extract (Coriandrum sativum L.) Against Phagocytosis Activity and Capacity of the Macrophage Cells and the Percentage of Leukocyte Cells in White Male Mice. Pharmacog J. 2019;11 (6):1290-8. 
Dillasamola, et al:: The Effect of Coriander Ethanol Extract (Coriandrum sativum L.) Against Phagocytosis Activity and Capacity of the Macrophage Cells and the Percentage of Leukocyte Cells in White Male Mice

(Olympus), container (bottle), mortar and pestle (PRC), glass object (Deckglaser), test tube (Iwaki), TLC (Merck) plate, rotary evaporator (BUTCHI R-210), Erlenmeyer (Pyrex), incubator (Gallenkamp plus), centrifuge (Oregon), animal scales, maceration bottles, mice cages, drop pipettes, vials, spatulas, surgical scissors, places to eat and drink mice, vessels, ose needles.

\section{Materials}

The ingredients used were coriander (Coriandrum sativum,. L) aquadest ( Gio Farma), ethanol (Building Andalas), distilled water, toluene (Emsure), ethyl acetate (Building Andalas), dichloromethane (Building Andalas), Staphylococcus aureus, nutrient agar (Merck), nutrient broth (Merck), physiological $\mathrm{NaCl}$ (PT Widatra Bhakti), $\mathrm{Na}$ CMC 0,5 \%, Giemsa dye (Merck), Turk solution (PT. Sagara Husada Mandiri) and white male mice.

\section{Extract making}

Two kg of finely grounded coriander were macerated using ethanol. One part of the simplicial dry powder was added to the macerator, then 10 parts of the solvent were added after. This powder was soaked for the first six hours while being stirred occasionally, then it was sat for 18 hours before strained. This extraction process was being repeated until a clear filtrate was obtained. The macerates that were obtained then being evaporated with a rotary evaporator until a thick extract was obtained

\section{Preparation of the experimental animals}

The animals used were white male mice aged 2-3 months with an average weight of 20-30 grams which were 20 mice in total and divided into 4 groups. Each group consists of 5 mice. Before they were treated, the mice were acclimatized for 7 days with enough food and water.

\section{Dosage determination}

The dose of coriander ethanol extract used for this study was given in 3 variants doses; $100 \mathrm{mg} / \mathrm{kg}, 140 \mathrm{mg} / \mathrm{kg}$ and $200 \mathrm{mg} / \mathrm{kg}$ (Tables 1 and 2).

\section{Bacterial culture}

Staphylococcus aureus (SA) was bred on nutrient agar (NA). One SA culture was inoculated into the new NA medium, then was incubated at $37^{\circ} \mathrm{C}$ for 24 hours in the incubator. Staphylococcus aureus which grown on nutrient agar media (NA) was transferred to the nutrient broth media (NB), incubated for 24 hours at $37^{\circ} \mathrm{C}$, then was centrifuged at $2500 \mathrm{rpm}$ for 25 minutes before it formed pellets and suspended with $0.9 \% \mathrm{NaCl}$ which equivalent with Mc Farland solution 0.5 (10).

The activity and capacity test of the phagocytosis of macrophage cells

After the acclimatization and the mice were already given with extract preparations for 7 days long, at the $8^{\text {th }}$ day the mice in each group were infected with $0.5 \mathrm{~mL}$ suspension of Staphylococcus aureus bacteria intraperitoneally, then left for 1 hour. The mice then were killed and dissected. Peritoneal fluid was taken using a micropipette. The peritoneal liquid was made into smear preparations on an object glass, then fixed with absolute methanol for 5 minutes, was stained with Giemsa, and left for 20 minutes before it was rinsed with running water and being dried off. Preparations were seen under microscope light using emersion oil at 1000x magnification. Phagocytosis activity of macrophage cells is determined based on the number of phagocytic cells that actively carrying out phagocytosis in 100 phagocytic cells. The phagocytosis capacity of macrophage cells is determined based on the number of Staphylococcus aureus bacteria which are phagocytosis by 50 active phagocytic cells.
$\%$ Macrophage Activity $=\begin{gathered}\text { Total of active macrophage } \\ 100 \text { macrophage }\end{gathered} \times 100 \%$

Macrophage Capacity $=$ The number of bacteria that was phagocyted by 50 active macrophage cells.

\section{Calculating the percentage of leukocyte cells}

On the eighth day, the mice's tails were cut and the blood smear was made and dried. After the dried off, it was dripped with methanol, so it could cover the entire blood smear and left for 5 minutes. The blood smear then was coloured with Giemsa and left for 20 minutes before it was washed with distilled water, dried, added with emersion oil, and then observed under the ocular microscope. The counted number of eosinophil cells, stem neutrophils, neutrophil segments, lymphocytes, and monocytes were at $1000 \mathrm{x}$ magnification. ${ }^{11}$

\section{Calculating the total number of leukocyte cells}

The mice's fresh blood was taken up to 0.5 with leukocytes pipette. Turk solution was taken up to the $11^{\text {th }}$ sign, then was shaken for 3 minutes long. 1-2 drops were thrown from leukocytes pipette and one drop was used for the hemocytometer counting room. The liquid was left for 2 minutes until the leukocytes settled up. The number of leukocytes was calculated at the four corners of the calculating chamber. ${ }^{11}$

Total of Leukocytes cell = Leukocytes cell $\times 20 \quad 0,4$

Data analysis

The data that were obtained was analyzed statistically by one-way variation analysis (ANOVA) method, then continued with Duncan's analysis.

\section{RESULT}

The preparation process of coriander extract was started from separating the dried corianders from its impurity and refining it out. The maceration of coriander ethanol extract was evaporated by rotary evaporator at $50^{\circ} \mathrm{C}$ to condensed the concentration of the solution so that coriander extract can be obtained without any mixture of ethanol solvent. The rotary results obtained a thick viscous extract of coriander at $59.5498 \mathrm{~g}$, with a yield value of $2.9775 \%$. Standardization of extracts was carried out after obtaining thick coriander extract. The purpose of standardization is to obtain safe extraction and tested stability so that the quality of the stock obtained is guaranteed. ${ }^{12}$

The TLC test is useful for identifying linalool compounds that can be found in coriander extract. The mobile phase used is toluene: ethyl acetate with a ratio of 93:7. The stationary phase used is silica gel 60 F254. The Rf value of the linalool compound is 0.3 and $0.3 \%$ of the coriander ethanol extract was obtained. The ash content that was obtained from coriander thick extract was $7.03 \%$, while the drying shrinkage was $9.9 \%$. Based on the phytochemical test it was found that coriander extract positively contained phenolic compounds, flavonoids, triterpenoids, and steroids.

The phagocytosis process of macrophage cells can be seen in Figures 1 and 2 . The results that were obtained from the calculation of phagocytic activity of macrophage cells after the administration of coriander ethanol extract was each $41.20 \%$ (group I, control); $44.60 \%$ (group II, dose of $100 \mathrm{mg} / \mathrm{kg}$ ); $54.20 \%$ (group III, dose of $140 \mathrm{mg} / \mathrm{kg}$ ); and $60.20 \%$ (group IV, dose of $200 \mathrm{mg} / \mathrm{kg}$ ) in average, which can be seen in Tables 5 and 6 . The relationship between 4 groups of doses in white male mice with the percentage of phagocytic activity of macrophage cells can be seen in Figure 3. The results show an increase in the average phagocytic activity of macrophage cells. Based on the statistical analysis of oneway ANOVA, there were significant differences from the four groups 
Dillasamola, et al:: The Effect of Coriander Ethanol Extract (Coriandrum sativum L.) Against Phagocytosis Activity and Capacity of the Macrophage Cells and the Percentage of Leukocyte Cells in White Male Mice

Table 1: Organoleptic observation of coriander ethanol extract.

\begin{tabular}{ccc}
\hline Organoleptic Components & Herbal Pharmacopeia Indonesia & Observation Result \\
\hline Shape & Thick extract & Thick extract \\
Color & Brown & Brown \\
Odor & Specific odor & Specific odor \\
Taste & Slightly spicy & Slightly spicy \\
\hline
\end{tabular}

Table 2: Calculation results of the phagocytic activity percentage of macrophage cells in white male mice after given with coriander ethanol extract.

\begin{tabular}{|c|c|c|c|c|}
\hline \multirow{3}{*}{ Mice } & \multicolumn{4}{|c|}{ Phagocytic activity percentage of macrophage cells (\%) } \\
\hline & \multirow{2}{*}{ 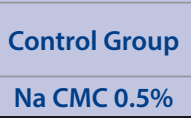 } & \multicolumn{3}{|c|}{$\begin{array}{l}\text { Groups that were given with coriander (Coriandrum sativum L.) ethanol } \\
\text { extract suspension }\end{array}$} \\
\hline & & $100 \mathrm{mg} / \mathrm{kg}$ & $140 \mathrm{mg} / \mathrm{kg}$ & $200 \mathrm{mg} / \mathrm{kg}$ \\
\hline 1 & 41 & 43 & 55 & 61 \\
\hline 2 & 45 & 42 & 54 & 60 \\
\hline 3 & 41 & 45 & 57 & 56 \\
\hline 4 & 40 & 43 & 55 & 56 \\
\hline 5 & 39 & 50 & 50 & 68 \\
\hline Average & 41,200 & 44,600 & 54,200 & 60,200 \\
\hline SD & 2,280 & 3,209 & 2,588 & 4,919 \\
\hline
\end{tabular}

Table 3: One-way ANOVA test results on phagocytosis activity of macrophage cells in white male mice after the administration of coriander ethanol extract.

\begin{tabular}{cc}
\hline & sig \\
\hline Between Groups & 0,000 \\
In Groups & \\
Total & \\
\hline
\end{tabular}

Table 4: Duncan's continued test results on phagocytic activity of macrophage cells in white male mice after given by coriander ethanol extract.

\begin{tabular}{ccccc}
\hline \multirow{2}{*}{ Group } & N & \multicolumn{3}{c}{ Subset } \\
\cline { 3 - 4 } & & 1 & 2 & 3 \\
\hline I & 5 & 41,200 & \\
II & 5 & 44,600 & & \\
III & 5 & & 54,200 & 60,200 \\
IV & 5 & & & 1,000 \\
Sig & & 0,134 & 1,000 & \\
\hline
\end{tabular}

Table 5: Calculation results of phagocytosis capacity of macrophage cells in white male mice after given with coriander fruit ethanol extract.

\begin{tabular}{|c|c|c|c|c|}
\hline \multirow{3}{*}{ Mice } & \multicolumn{4}{|c|}{ Phagocytosis capacity of macrophage cells } \\
\hline & \multirow{2}{*}{$\begin{array}{c}\text { Control Group } \\
\mathrm{Na} \text { CMC } 0.5 \%\end{array}$} & \multicolumn{3}{|c|}{ Groups that were given with coriander (Coriandrum sativum L.) ethanol extract suspension } \\
\hline & & $100 \mathrm{mg} / \mathrm{kg}$ & $140 \mathrm{mg} / \mathrm{kg}$ & $200 \mathrm{mg} / \mathrm{kg}$ \\
\hline 1 & 87 & 90 & 102 & 127 \\
\hline 2 & 79 & 97 & 89 & 125 \\
\hline 3 & 86 & 94 & 116 & 121 \\
\hline 4 & 90 & 96 & 107 & 127 \\
\hline Average & 81,400 & 95,800 & 104,400 & 126,000 \\
\hline SD & 10,015 & 4,382 & 9,965 & 3,317 \\
\hline
\end{tabular}

Table 6: One-way ANOVA test results on phagocytosis capacity of white male mice macrophage cells after the administration of coriander ethanol extract.

\begin{tabular}{cc}
\hline & sig \\
\hline Between Groups & 0,000 \\
In Groups & \\
Total & \\
\hline
\end{tabular}


Dillasamola, et al:: The Effect of Coriander Ethanol Extract (Coriandrum sativum L.) Against Phagocytosis Activity and Capacity of the Macrophage Cells and the Percentage of Leukocyte Cells in White Male Mice

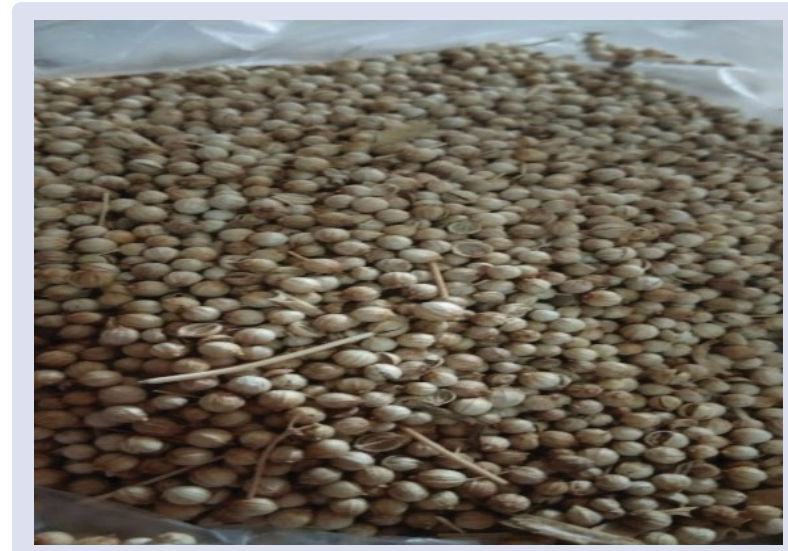

Figure 1: Coriander fruits.

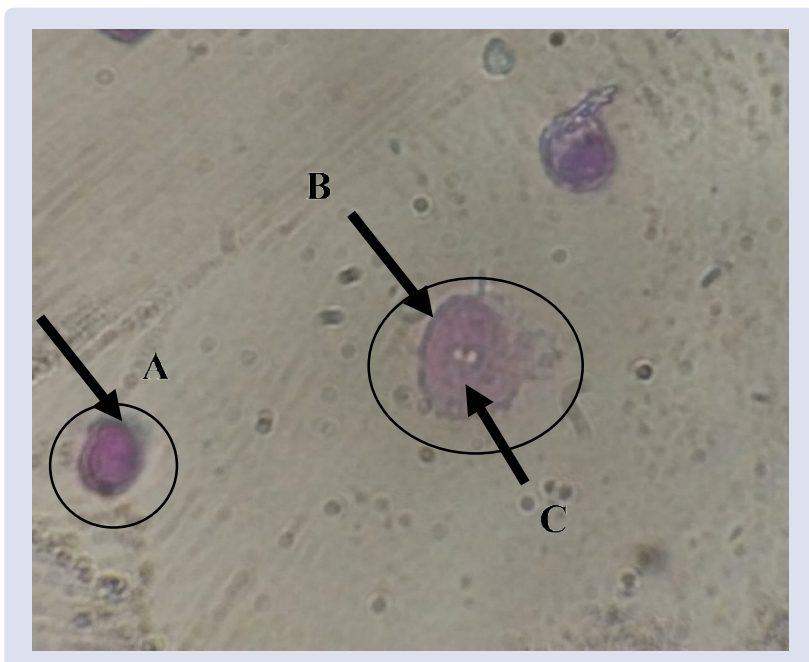

Figure 2: Peritoneal macrophage cells of white male mice observation under a microscope with 1000x magnification. Notes: $A=$ Macrophage; $B=$ Active macrophage; $C=$ Staphylococcus aureus bacteria

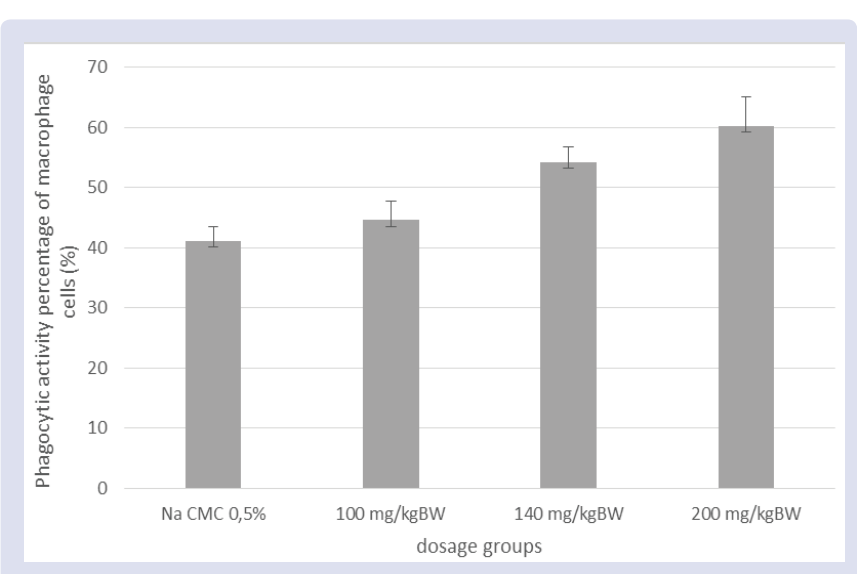

Figure 3: A graphic of relationship between phagocytic activity of macrophage cells with the group of mice after given with coriander ethanol extract. From the graph, an increase in each dosage groups was obtained with with an optimum dosage of $200 \mathrm{mg} / \mathrm{kgBW}$.

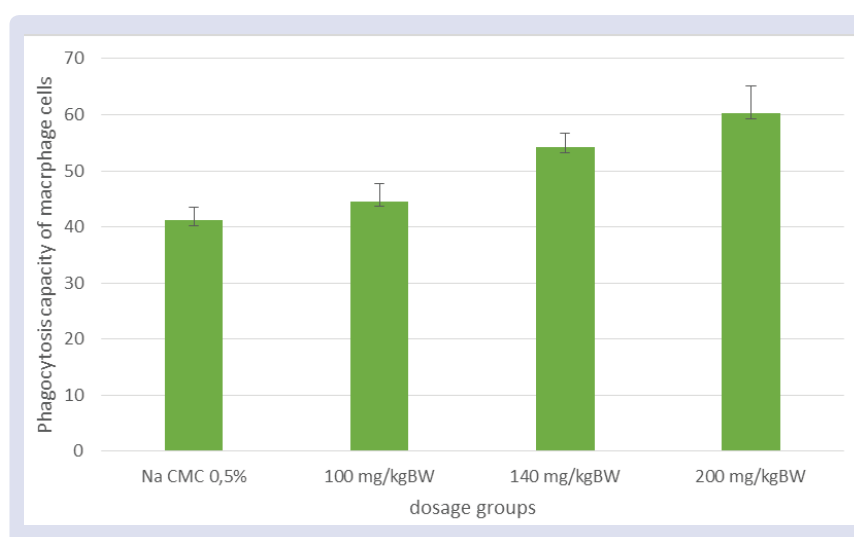

Figure 4: A graphic of relationship between phagocytosis capacity of macrophage cells and mice group after the administration of coriander ethanol extract. From the graph, an increase in each dosage groups was obtained with with an optimum dosage of $200 \mathrm{mg} / \mathrm{kgBW}$.

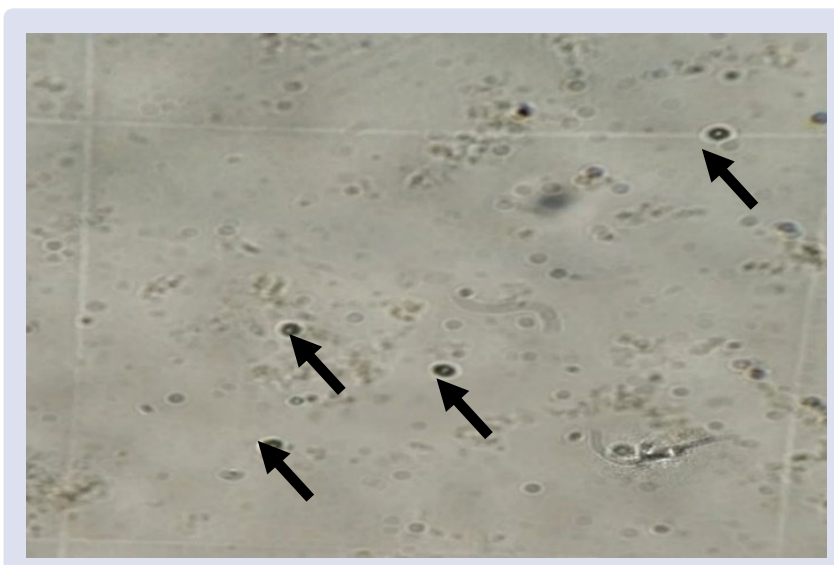

Figure 5: White male mice's leukocyte cells observed with hemocytometer at $400 x$ magnification.

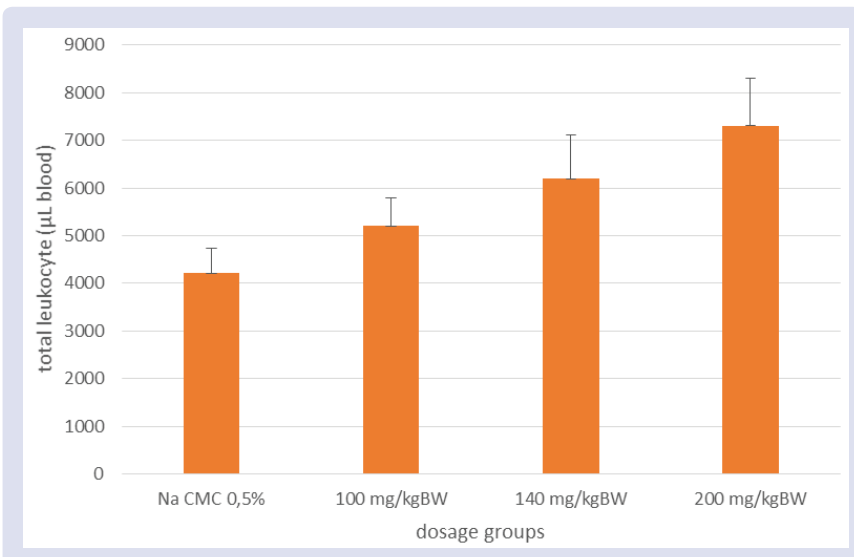

Figure 6: A graphic of relationship between total leukocyte cells and the groups of mice after given with coriander ethanol extract. From the graph, an increase in each dosage groups was obtained with with an optimum dosage of $200 \mathrm{mg} / \mathrm{kgBW}$. 
$(\mathrm{p}<0.05)$. Furthermore, Duncan's continued test analysis was carried out to find out the significant differences between the four groups. Duncan's continued test showed that group I and II had no significant differences, but there were significant differences in groups III and IV.

Calculation results of the phagocytosis capacity of macrophage cells after coriander ethanol extract administration also experienced an increase; group I with 81.40 cells; group II with 91.80 cells; group III 104.40 with cells; and group IV with 126.00 cells which can be seen in Table VI. The relationship between 4 groups of doses of white male mice with the percentage of phagocytic activity of macrophage cells can be seen in Figure 4. The test of ANOVA statistical analysis showed a significant increase $(\mathrm{p}<0.05)$. Duncan's continued test showed that between groups II and III there were no significant differences, but there were significant differences between group I and IV. According to previous studies, secondary metabolites contained in extracts such as flavonoids, tannins, triterpenoids, and saponins are effective as immunomodulators and increase phagocytosis activity and capacity of macrophage cells. Flavonoid compounds have the ability to be antiinflammatory and improve the immune system. ${ }^{13}$

Based on the calculation results that were obtained, an increase was found in total leukocyte cells from the four groups. The highest leukocyte cells increase was found at a dose of $200 \mathrm{mg} / \mathrm{kg}$, namely $7,310 / \mu \mathrm{L}$ of blood which can be seen in Table VII. The relationship between the 4 groups doses of white male mice with the total number of leukocyte cells can be seen in Figures 5 and 6 . The one-way ANOVA statistical test showed that there were significant differences between the four groups $(\mathrm{p}<0.05)$. Duncan's continued test analysis shows that there are subset 1 in group I and II which means there are no significant differences between the two groups, but there are significant differences in groups III and IV. According to previous studies, certain chemical compounds in plant extracts can stimulate leukocyte production and function as an immune booster in the body. ${ }^{14}$

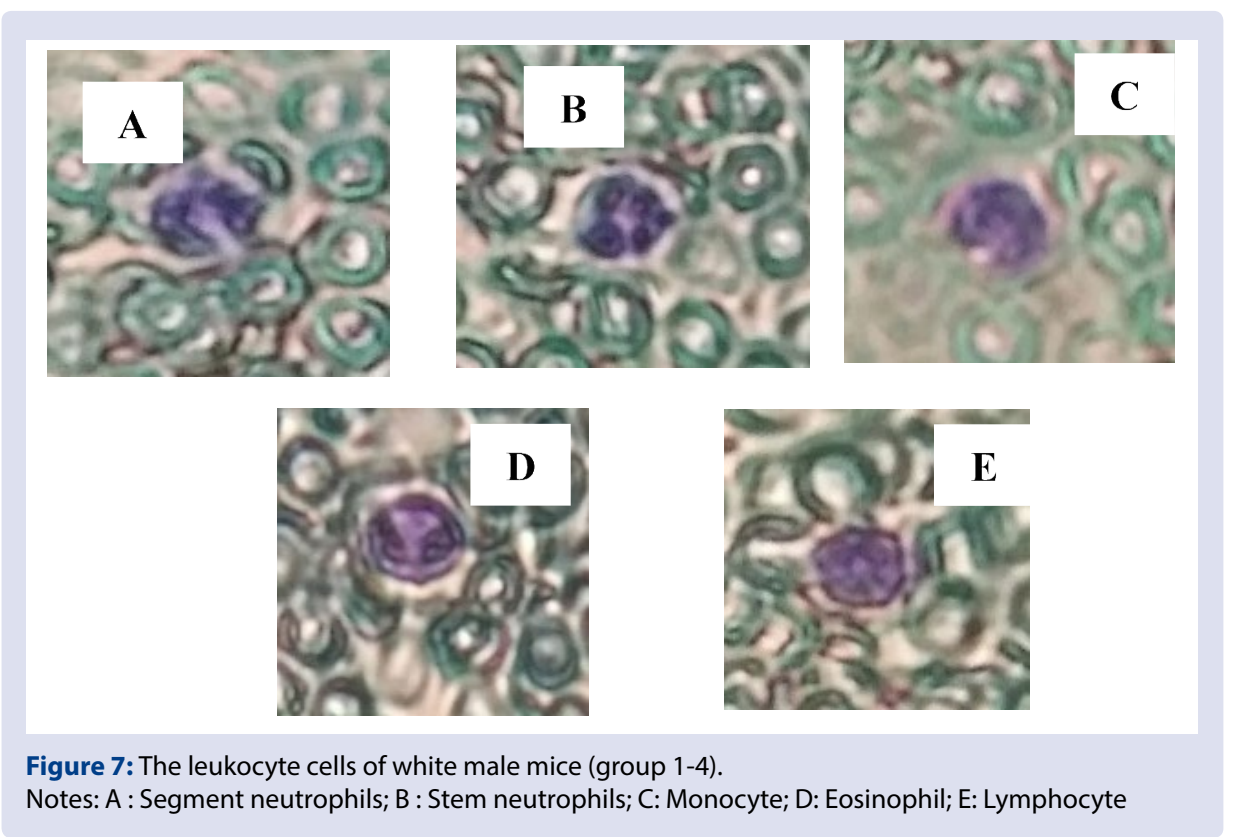

Figure 7: The leukocyte cells of white male mice (group 1-4).
Notes: A : Segment neutrophils; B : Stem neutrophils; C: Monocyte; D: Eosinophil; E: Lymphocyte

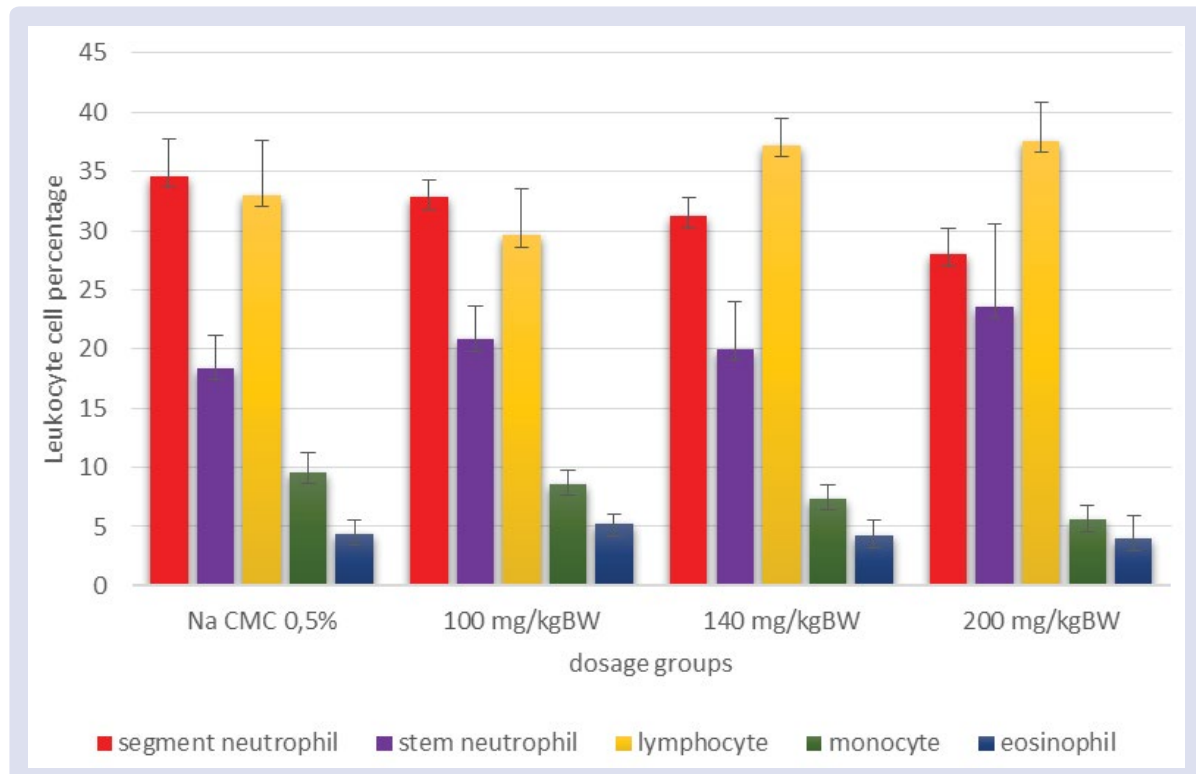

Figure 8: A graphic of relationship between the percentage of leukocyte cells and groups of mice after given with coriander ethanol extract. The graph shows a decrease in the calculation of segment neutrophil cells and monocyte cells. 
Dillasamola, et al:: The Effect of Coriander Ethanol Extract (Coriandrum sativum L.) Against Phagocytosis Activity and Capacity of the Macrophage Cells and the Percentage of Leukocyte Cells in White Male Mice

Table 7: Duncan's continued test results on phagocytosis capacity of macrophage cells in white male mice after given with coriander ethanol extract.

\begin{tabular}{ccccc}
\hline Group & N & \multicolumn{3}{c}{ Subset } \\
\cline { 3 - 4 } & & $\mathbf{1}$ & $\mathbf{2}$ & 3 \\
\hline I & 5 & 81,400 & \\
II & 5 & & 95,800 & \\
III & 5 & & 104,400 & 126,00 \\
IV & 5 & & & 1,000 \\
Sig & & 0,100 & 0,092 & \\
\hline
\end{tabular}

Table 8: The calculation results of the total number of leukocyte cells in white male mice after the administration of coriander ethanol extract.

\begin{tabular}{|c|c|c|c|c|}
\hline \multirow{3}{*}{ Mice } & \multicolumn{4}{|c|}{ Total Leukocytes $(/ \mu \mathrm{L}$ blood $)$} \\
\hline & \multirow{2}{*}{$\begin{array}{l}\text { Control Group } \\
\mathrm{Na} \mathrm{CMC} 0.5 \% \\
\end{array}$} & \multicolumn{3}{|c|}{ Groups that were given with coriander (Coriandrum sativum L.) ethanol extract suspension } \\
\hline & & $100 \mathrm{mg} / \mathrm{kg}$ & $140 \mathrm{mg} / \mathrm{kg}$ & $200 \mathrm{mg} / \mathrm{kg}$ \\
\hline 2 & 4.600 & 4.500 & 7.300 & 7.400 \\
\hline 3 & 3.550 & 5.700 & 7.050 & 6.350 \\
\hline Average & 4.210 & 5.210 & 6.190 & 7.310 \\
\hline SD & 530,801 & 584,594 & 920,190 & 993,353 \\
\hline
\end{tabular}

Table 9: One-way ANOVA test results of total leukocyte cells in white male mice after given with coriander ethanol extract.

\begin{tabular}{cc}
\hline & sig \\
\hline Between Groups & 0,000 \\
In Groups & \\
Total & \\
\hline
\end{tabular}

Table 10: Duncan's continued test results on total leukocyte cells after the white male mice given by coriander fruit ethanol extract.

\begin{tabular}{ccccc}
\hline \multirow{2}{*}{ Group } & N & \multicolumn{3}{c}{ Subset } \\
\cline { 3 - 4 } & & 5 & $\mathbf{2}$ & $\mathbf{3}$ \\
\hline I & 5 & 4210,000 & \\
II & 5 & 5210,000 & \\
III & 5 & & 6190,000 & 7310,000 \\
IV & 5 & & & 1,000 \\
Sig & & 0,061 & 0,066 & \\
\hline
\end{tabular}

The calculation results of leukocyte cells observation can be seen in Table V. The relationship between 4 groups of doses in white male mice and leukocyte cells can be seen in Figures 7 and 8. One-way ANOVA test results and Duncan's continued test showed that in eosinophil cells, lymphocytes, and stem neutrophils were not present a significant difference ( $p>0.05)$. In one-way ANOVA analysis, segment neutrophils showed significant differences $(p<0.05)$. Duncan's continued test results showed that there were no significant differences as well in the group I and II as well as in group II and III. Significant differences exist between the first three groups with group IV. The calculation results show that segment neutrophils has decreased. The decrease is suspected because the phagocytosis process which has more role is macrophages or because of the increase in chemotaxis factors resulting in an increase in phagocytosis. The results of the one-way ANOVA test for monocyte cells showed a significant difference $(\mathrm{p}<0.05)$. Duncan's continued test showed that there were no significant differences in the group I and II as well as in group II and III. Significant differences exist between the first three groups with group IV. The calculation result of monocyte cells showed a decrease. This is presumably because of monocyte cells differentiated into macrophages and settled on the tissue.

\section{DISCUSSION/ CONCLUSION}

The results of the research that have been carried out show that the ethanol extract of coriander can increase the phagocytosis activity and capacity of macrophage cells and the percentage of leukocyte cells in white male mice with an optimum dose of $200 \mathrm{mg} / \mathrm{kg}$. This happens in accordance with the chemical compounds contained in coriander fruit, flavonoids, which play a role as immunomodulators. The content of flavonoids, according to existing research, has the potential as an antioxidant for tumour growth. It can increase the immune response and work against lymphokines produced by $\mathrm{T}$ cells so that it will stimulate phagocytic cells to respond for phagocytosis. ${ }^{15}$ Previous studies have also shown that Coriandrum sativum not only acts as an additive in food but also can enhance immune responses (immunomodulators) so it's a good use for inducing various levels of disease resistance. ${ }^{16,17}$

Based on the research that has been done, it can be concluded that ethanol extract of coriander fruit can increase the phagocytic activity of white male mice's macrophage cells with optimum doses of $200 \mathrm{mg} /$ $\mathrm{kg}$. Ethanol extract of coriander fruit can increase the total number of 
Dillasamola, et al:: The Effect of Coriander Ethanol Extract (Coriandrum sativum L.) Against Phagocytosis Activity and Capacity of the Macrophage Cells and the Percentage of Leukocyte Cells in White Male Mice

Table 11: The calculation results of leukocyte cells in white male mice after the administration of coriander (Coriandrum sativum L.) ethanol extract.

\begin{tabular}{|c|c|c|c|c|c|c|}
\hline & Mice & Segment Neutrophil (\%) & Stem Neutrophil (\%) & Eosinophil (\%) & Lympho-cyte (\%) & Mono-cyte (\%) \\
\hline \multirow{7}{*}{$\mathrm{Na} C M C 0.5 \%$} & 1 & 38 & 17 & 4 & 33 & 8 \\
\hline & 2 & 36 & 18 & 3 & 33 & 10 \\
\hline & 3 & 30 & 20 & 4 & 34 & 12 \\
\hline & 4 & 33 & 15 & 5 & 39 & 8 \\
\hline & 5 & 36 & 22 & 6 & 26 & 10 \\
\hline & Average & 34,600 & 18,400 & 4,400 & 33,000 & 9,600 \\
\hline & SD & 3,130 & 2,702 & 1,140 & 4,637 & 1,673 \\
\hline \multirow{7}{*}{$\begin{array}{c}\text { Dose } \\
100 \mathrm{mg} / \mathrm{kg}\end{array}$} & 1 & 33 & 18 & 4 & 37 & 8 \\
\hline & 2 & 32 & 19 & 4 & 36 & 9 \\
\hline & 3 & 31 & 22 & 5 & 33 & 9 \\
\hline & 4 & 35 & 20 & 3 & 35 & 7 \\
\hline & 5 & 33 & 25 & 5 & 27 & 10 \\
\hline & Average & 32,800 & 20,800 & 5,200 & 29,600 & 8,600 \\
\hline & SD & 1,483 & 2,775 &, 837 & 3,975 & 1,140 \\
\hline \multirow{7}{*}{$\begin{array}{c}\text { Dose } \\
140 \mathrm{mg} / \mathrm{kg}\end{array}$} & 1 & 33 & 15 & 5 & 40 & 7 \\
\hline & 2 & 32 & 18 & 5 & 38 & 7 \\
\hline & 3 & 32 & 26 & 2 & 34 & 6 \\
\hline & 4 & 30 & 20 & 4 & 38 & 8 \\
\hline & 5 & 29 & 21 & 5 & 36 & 9 \\
\hline & Average & 31,200 & 20,000 & 4,200 & 37,200 & 7,400 \\
\hline & $\mathrm{SD}$ & 1,643 & 4,062 & 1,304 & 2,280 & 1,140 \\
\hline \multirow{7}{*}{$\begin{array}{c}\text { Dose } \\
200 \mathrm{mg} / \mathrm{kg}\end{array}$} & 1 & 25 & 27 & 4 & 38 & 6 \\
\hline & 2 & 27 & 28 & 3 & 36 & 6 \\
\hline & 3 & 28 & 20 & 5 & 40 & 7 \\
\hline & 4 & 29 & 30 & 4 & 33 & 4 \\
\hline & 5 & 31 & 13 & 8 & 41 & 7 \\
\hline & Average & 28,000 & 23,600 & 4,000 & 37,600 & 5,600 \\
\hline & SD & 2,236 & 7,021 & 1,924 & 3,209 & 1,225 \\
\hline
\end{tabular}

Table 12: One-way ANOVA test results of leukocyte cells in male white mice after given with coriander ethanol extract.

\begin{tabular}{|c|c|c|}
\hline & & Sig \\
\hline \multirow{3}{*}{ Segment Neutrophils } & Between groups & 0,002 \\
\hline & In groups & \\
\hline & Total & \\
\hline \multirow{3}{*}{ Stem Neutrophils } & Between groups & 0,351 \\
\hline & In groups & \\
\hline & Total & \\
\hline \multirow{3}{*}{ Lymphocyte } & Between groups & 0,133 \\
\hline & In groups & \\
\hline & Total & \\
\hline \multirow{3}{*}{ Monocyte } & Between groups & 0,003 \\
\hline & In groups & \\
\hline & Total & \\
\hline \multirow{3}{*}{ Eosinophil } & Between groups & 0,884 \\
\hline & In groups & \\
\hline & Total & \\
\hline
\end{tabular}

Table 13: Duncan's continued test results of segment neutrophil cells in white male mice after coriander ethanol extract administration.

\begin{tabular}{ccccc}
\hline \multirow{2}{*}{ Group } & N & \multicolumn{3}{c}{ Subset } \\
\cline { 3 - 5 } & & & 2 & 3 \\
\hline I & 5 & & 32,800 & 32,800 \\
II & 5 & & 31,200 & \\
III & 5 & & & \\
IV & 5 & 28,000 & 0,271 & 0,218 \\
sig & & 1,000 & 000 \\
\hline
\end{tabular}


Dillasamola, et al: The Effect of Coriander Ethanol Extract (Coriandrum sativum L.) Against Phagocytosis Activity and Capacity of the Macrophage Cells and the Percentage of Leukocyte Cells in White Male Mice

Table 14: Duncan's continued test results of monocyte cells in white mice male after coriander ethanol extract administration.

\begin{tabular}{ccccc}
\hline \multirow{2}{*}{ Group } & N & \multicolumn{3}{c}{ Subset } \\
\cline { 3 - 5 } & 5 & & 2 & 3 \\
\hline I & 5 & & 8,600 & 9,800 \\
II & 5 & & 7,400 & \\
III & 5 & 6,000 & & \\
IV & & 0,111 & 0,168 & 0,246 \\
sig & & &
\end{tabular}

leukocyte cells and decrease the number of segment neutrophils and monocytes in white male mice with an optimum dose of $200 \mathrm{mg} / \mathrm{kg}$.

\section{ACKNOWLEDGMENT}

The authors would like to thank the Faculty of Pharmacy, Andalas University, Indonesia for funding this research.

\section{CONFLICTS OF INTEREST}

There is no conflicts of interest in this study.

\section{REFERENCES}

1. Kresno S. Immunology: Diagnosis and Laboratory Procedures 5. Jakarta Edition: FKUI Press.

2. Hasdianah. Molecular Biology Diagnosis and Techniques. Yogyakarta: Nuha Medika; 2014

3. Baratawidjaja RI. Basic Immunology Edition 10. jakarta: FKUI Publisher Center.

4. Liu G, Wu C, Wu Y, Zhao Y. Phagocytosis of apoptotic cells and immune regulation. Scand J Immunol. 2006;64(1):1-9.

5. Haas A. The phagosome: Compartment with a license to kill. Traffic. 2007;8(4):311-30

6. Anwar F, Hamid AA, Saari N, Sahib NG, Alkharfy KM, Gilani A-H. Coriander (Coriandrum sativum L.): A potential source of high-value components for functional foods and nutraceuticals - a review. Phyther Res. 2012.

7. Pathak Nimish L, Kasture Sanjay B, Bhatt Nayna M, Rathod Jaimik D. Phytopharmacological properties of coriander sativum as a potential medicinal tree: An overview. J Appl Pharm Sci. 2011;1(4):20-5.
8. Ahmed EHJ, Abadi RSM, Mohammed AMA. Phytochemical screening, chemical composition and antioxidant activity of seeds essential oil of Coriandrum sativum L. from the Sudan. 2018;6(1):1-4.

9. Cu R, Learning $H$. Isolation and simultaneous detection of flavonoids in the methanolic and ethanolic extracts of Coriandrum sativum L. seeds by RPHPLC. Pak J Food Sci. 2011;21(1-4):13-21.

10. Aldi Y, Aria M, Erman L. Test the immunostimulation effect of ciplukan (Physalis angulata L.) ethanol extract on the activity and capacity of phagocytosis of macrophage cells in female white mice. Scientia. 2016;4(1):38-42.

11. AldiY, Dewi ON, Uthia R. Immunomodulatory test and the number of leukocyte cells from basil (Ocicum basilicum L.) leaf extracts in male mice. Sci Farm and Health. 2016;6(2):139-47.

12. RI Ministry of Health. Indonesian Herbal Pharmacopoeia. Jakarta: Directorate General of Drug and Food Control; 2008.

13. Pérez-Cano FJ, Castell M. Flavonoids, inflammation and immune system Nutrients. 2016;8(10):8-11.

14. Ladokun $\mathrm{O}$, Ojezele $\mathrm{M}$, Arojojoye O. Comparative study on the effects of aqueous extracts of viscum album (Mistletoe) from three host plants on hematological parameters in albino rats. Afr Health Sci. 2015;15(2):606-12.

15. Caut $S$, Angulo $E$, Courchamp F. Discrimination factors $\left(\Delta^{15} \mathrm{~N}\right.$ and $\left.\Delta^{13} \mathrm{C}\right)$ in an omnivorous consumer: effect of diet isotopic ratio. Functional Ecology. 2008;22:255-63.

16. Innocent BX, Fathima MSA, Dhanalakshmi D. Studies on the immouostimulant activity of coriandrum sativum and resistance to aeromonas hydrophila in catla catla. J Appl Pharm Sci. 2011;1(7):132-5.

17. Mahendra $P$, Bisht $S$. Coriandrum sativum: A daily use spice with great medicinal effect. Pharmacogn J. 2011;3(21):84-8.

\section{GRAPHICAL ABSTRACT}

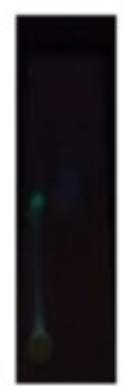

Characteritation

TLC of

C sativum

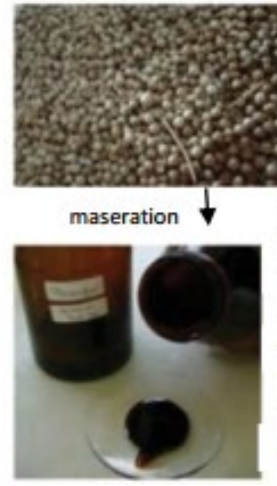

Extract of coriander fructus
NA CMC 0,5\%

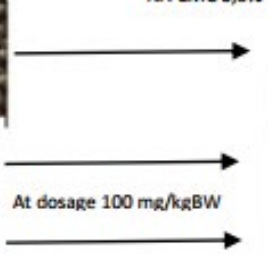

At dosage $140 \mathrm{mg} / \mathrm{kgBW}$

At dosage $200 \mathrm{ma} / \mathrm{kgBW}$
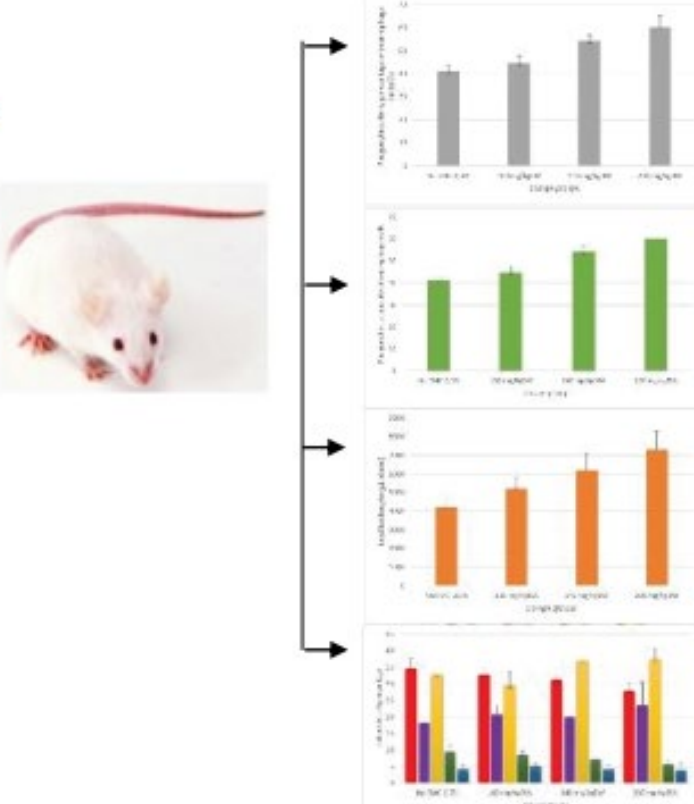


\section{SUMMARY}

Coriander fructus has been used as a medicine and reported could be used as anti-inflammation, antibacterial, anti tumor etc. This study use to determine the effect of coriander fruit ethanol extract on phagocytosis activity and capacity of macrophage cells and leukocyte percentage The test animals used were male white mice that were divided into 4 groups, each of which consisted of 5 mice. The first group was the control given $0.5 \% \mathrm{CMC} \mathrm{Na}$, the second group, three and four, were given ethanol extract of coriander fruit at a dose of $100 \mathrm{mg} / \mathrm{kgBW}, 140 \mathrm{mg} / \mathrm{kgBW}$ and $200 \mathrm{mg} / \mathrm{kgBW}$ orally for 7 days. On the 8 th day mice were induced with Staphlococcus aureus bacteria intraperitoneally. The result showed that coriander at doses of 100,140 and $200 \mathrm{mg} / \mathrm{kgBW}$ can increase activity, phagocytosis capacity of macrophage cells and total leukocyte cell counts of male white mice. It was significantly different $(p<0.05)$.

\section{ABOUT AUTHORS}

Dwisari Dillasamola,M.Farm, Apt: Currently as a lecturer functional positions at the Faculty of Pharmacy, Andalas University. Graduated from Faculty of Pharmacy Andalas University in 2004, then Master Program at Faculty of Pharmacy Andalas University in 2011. The research and expertise are in Farmaco-Immunology. Currently working as lecturer of FarmacoImmunology and Clinical-pharmacy of Faculty of Pharmacy, Andalas University.

Dr. Drs. Yufri Aldi, M.S.i., Apt.: Currently as a lecturer at the Faculty of Pharmacy, Andalas University. Graduated from Faculty of Pharmacy Andalas University in 1989, then Master Program in 1994 at School of Pharmacy Institut Teknlogi Bandung (ITB Bandung) and Doctoral Program in Department Biomedical, Faculty of Medicine, Andalas University in 2013. The research and expertise are in Farmaco-Immunology. Currently working as an assistant to the First Vice-Rector of Andalas University and Head of the Department Doctoral Programme Pharmacy of Faculty of Pharmacy, Andalas University.

Marselani Kolobinti: She is a student in Faculty of Pharmacy Andalas University who have been involved in assisting in the study of the effect of coriander ethanol extract on activities and phagocytosis capacity of macrophage cells and male white mice leukocyte cells percentage.

Cite this article: Dillasamola D, Aldi Y, Kolobinti M. The Effect of Coriander Ethanol Extract (Coriandrum sativum L.) Against Phagocytosis Activity and Capacity of the Macrophage Cells and the Percentage of Leukocyte Cells in White Male Mice. Pharmacog J. 2019;11(6):1290-8. 